\title{
Use Of Humor In The Workplace
}

Janice Witt Smith, Winston-Salem State University, USA

Mak Khojasteh, Winston-Salem State University, USA

\begin{abstract}
Humor is an organizational tool which, when used appropriately, can be effective in facilitating a better work environment. Organizational benefits include increased group cohesion, reduced conflict (through reduced stress), increased leadership effectiveness, and improved communication. There are implications that humor in diverse groups, which relate to gender or ethnicity, must be used with caution.
\end{abstract}

Keywords: Humor; Organization; Leadership; Group Cohesion; Stress; Diversity; Communication

\section{INTRODUCTION}

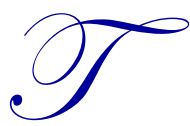

he national news headlines in the United States bring more and more negative news about the state of the U.S. and global economies. Transnational firms are laying off U.S. employees in record numbers and those who are employed struggle with lower wages and fewer benefits. In order for organizations to maintain or enhance their competitive positions and to strengthen financially, they must do more with fewer resources and do it better and more quickly than their competitors. Employee engagement strategies have proven effective to some extent, but over $40 \%$ of U.S. employees say that they are less than satisfied with their current employer and would leave if given the opportunity. This paper looks at an organizational tool that is readily available and can be effective, which could help reduce stress and frayed tempers and offer a respite for the workforce which is reeling from the changes in its environment. That tool is humor.

Mark Twain once said, "The human race has only one really effective weapon, and that is laughter. The moment it arises, all our hardnesses yield, all our irritations and resentments slip away, and a sunny spirit takes their place." Workplaces such as Yahoo, Southwest Airlines, Domino Pizza, Brady Corporation, Ben and Jerry, Odetics, Sun Micro System, and Kodak have encouraged use of fun and appropriate humor in the workplace and that culture seems to appeal to high-tech Millennials. Their stock prices have remained steady, comparatively speaking, in this volatile and turbulent economic environment.

Humor has been studied across disciplines, including business, communication, mental health, sociology, psychology, political science and anthropology. A substantial number of studies have been conducted based on the work of eminent anthropologist A.R. Radcliffe-Brown (1940, p. 195) who theorized that "what is meant by the term 'a joking relationship' is a relationship between two persons in which one is - by custom - permitted and, in some instances, required to tease or make fun of another who, in turn, is required to take no offense." Radcliffe-Brown indicates that one type of joking relationship is symmetrical in which each of the two-party members are able to be humorous and make fun of the other party while the other type is asymmetrical, where only one party uses humor and makes fun of the other party.

There are many definitions for humor, some of which include: 1) Encarta Dictionary [2013] defines humor as "the quality or content of something such as a story, performance or a joke that elicits amusement and humor"; 2) Martineau (1972) defines humor as "any communicative instance which is perceived as humorous"; 3) Chapman and Foot (1976) called humor "a process initiated by a humorous stimulus, such as a joke or cartoon, and terminating with some response indicative of experienced pleasure, such as laughter"; and 4) Winnick (1976) defined a joke as "a communication with a funny or witty intent that the teller knows in advance. This communication could be in the form of a witticism, pun or cartoon." The authors have chosen the following definition that most closely represents the scope of this article: Humor is an "amusing communication that produces positive emotions and cognitions in the individual, group, or organization (Romero \& Cruthirds, May 2006, p. 59). The discussion is limited to oral humor. 
The authors can examine humor through the use of humor styles to explain how it can be integrated into human and/or organizational life. These styles are: affiliative style, which is a non-hostile and funny behavior; selfenhancing style, which is a positive and coping mechanism to reduce stress; aggressive style, which is negative to reduce one's status and increase anxiety and tension; and self-defeating style to lower the status of self in order to gain acceptance (Martin et al., 2003). A closer examination of these styles ensues. Self-enhancing humor is typically used as a coping mechanism to deal with one's stressors and challenges. People who use this type of humor are typically easy-going (Martin et al., 2003) and "roll with the punches" (Kuiper, Martin \& Olinger, 1998). Affiliative humor is non-hostile and sometimes self-deprecating. This type of humor is always life affirming and can reduce tension and facilitative relationships (Martin et al., 2003). People who use this type of humor are perceived as likeable and non-threatening (Vaillant, 1977).

Aggressive humor can be either positive or negative. When used negatively, it manipulates or ridicules others (James \& Olson, 2000). Some research suggests that individuals using this behavior laugh whenever they feel superior to others. Thus, the more negative the aggressive humor, the higher the level of satisfaction the "bully" gains from the use of it (Zillman, 1983). Self-defeating humor is use of self-deprecation where one interjects humor at one's own expense. In this case, the individual is trying to raise their status of themselves to others. These individuals tend to be lower in self esteem and emotionally needy (Fabrizia \& Pollio, 1987).

Another approach to examining humor is through looking at its impact, whether it is positive or negative (Samson \& Gross, 2012). Positive humor is a functional behavior, while negative humor often leads to negative results. The authors can also examine whether or not the humor is spontaneous or planned.

Finally, the authors can look at theories of humor cited in Greatbatch and Clark (2003) for which Greig (1923) lists 88 different theories of laughter and humor. Raskin (1985) collapses those into three categories: 1) Psychoanalytic, whose primary concern is the release from psychological tensions, associated with Freud (cited in Gruner, 1997); 2) Cognitive-perceptual, which is associated with congruity; and 3) Social-behavioral, which is concerned with superiority and disparagement theories (Jenepher \& Ashforth, 2002). Psychoanalytic or relief theories examine humor from the perspective of laughter and humor in diffusing tension that has built up in the situation and/or the removal of the catalyst or initiator of that pain or discomfort (Berlyne, 1968). In these theories, Freud (1916) and others suggest that laughter and humor provide socially acceptable outlets for that repressed emotion, including aggression, to be released. Cognitive-perceptual theorists argue that the laughter is a result of the surprise from the resolution of cognitive dissonance and may express affection, malice of relief (Cetola, 1988; Berlyn, 1968). Disparagement and superiority theories view humor as a way that people disparage and laugh at others, using sarcasm and malice cloaked in so-called jokes or humorous and anxiety, when used appropriately in the correct context (Ullian, 1976).

\section{IMPLICATIONS OF HUMOR IN ORGANIZATION: POSITIVE ORGANIZATIONAL BEHAVIOR-POB}

Positive organizational behavior (POB) is a derivative of positive organizational psychology (POP), which is believed to be initiated by Seligman and Csikszenentmihalyi (2000) in the late 1990's and early 2000 (Luthans, 2002). POB addresses the lighter, brighter side of organizational behavior-OB, using constructs such as confidence, hope, happiness, organizational wellness and good life (Luthans, 2002).

Max Weber has influenced separation of humor from work since he approached organizations from a logical viewpoint, without allowing room for emotions. However, as organization science and knowledge advanced, humor created a significant role for itself. It has been viewed as a panacea for a variety of organizational problems. Research indicates that humor can be a possible source of psychic rewards and also a mechanism to relive frustration, alleviate boredom and facilitate transfer of information in a work setting (Duncan, 1982).

\section{HUMOR AND LEADERSHIP}

Leadership is one of the most important, complex and studied aspects of the organization. Humor is noted as an important characteristic associated with leadership (Bass, 1990; Shamir, 1995; Clouse \& Spurgeon, 1995). However, few researchers examined the relationship between humor and leadership (Avolio, Howell \& Sosik, 
1999). The variable "empowerment" is sometimes used with it. Empowerment, as one of the most effective tools to achieve organizational goals, is highly associated with the use of humor by the leader of the organization.

Leadership, using both positive and negative humor, is associated with empowerment with different outcomes. When the positive humor is applied, the outcome is positive, while the application of the negative humor results in a negative effect on employees' psychological empowerment. Interestingly, the tenured employee reacts more negatively toward the negative humor which substantially diminishes their feeling of psychological empowerment. The relationship with the new employee is different. New employees are affected with regard to the psychological empowerment mainly with positive humor of the leader (Gkorezis et al., 2011). Other researchers indicate that humor affects the enhancement of feelings of empowerment and eliminates interpersonal barriers which are associated with organizational hierarchy (Duncan \& Feisal, 1989) and shape the climate and establishes the informal social relationships in a work setting (Hatch \& Ehrlich, 1993; Heath, 1997).

Humor also plays a role in leadership styles. However, there is limited research that investigates the relationship between humor and leadership (Shamir, 1995; Bass, 1990). For example, in transactional leadership style, humor positively facilitates the exchange process between the leader and followers. Humor is also positively related to the transformational leadership. However, it is negatively related to the laissez-faire leadership style (Avolio et al., 1999).

There is a relationship between humor and leader effectiveness and relationship behavior. Positive humor is associated with enhancing leader effectiveness, while negative humor is significantly associated with decreasing relationship behaviors (Decker et al., 2001).

\section{HUMOR AND GROUP COHESION}

Another benefit of using humor in the workplace is work group cohesion. Jenepher and Ashforth (2002) found that "inclusionary putdown" humor helps temporary groups form a group identity and develop solidarity. Temporary groups include task forces, matrix teams, focus groups and project teams, contract and contingent workers and "have a finite life span, form around a shared and relatively clear goal or purpose, and their success depends on a tight and coordinated coupling of activity" (Meyerson et al., 1996, p. 167). Among the challenges faced by temporary groups, other than those typical of the five-step group development process (that is, forming, storming, norming, performing and adjourning), is that they typically have not worked together previously and probably will not again; each brings specialized expertise or talent and depends on each other for the successful completion of the task; and the tasks tend to be non-routine and non-repetitive (Goodman \& Goodman, 1976). Meyerson et al. (1996) suggest that these types of groups must develop "swift trust" - they do not have the time and opportunity to allow trust to develop slowly and to evolve over time. In these cases, group identity and solidarity must be formed quickly, and the literature suggests that inclusive putdown humor can be a means for achieving this.

In practical terms, "putdown humor" can be finding the use of insults, demeaning jokes, teasing, sarcasm or self-deprecating remarks toward someone else as amusing or humorous (Jenepher \& Ashforth, 2002). RadcliffeBrown (1940, p. 197) found that as long as the two individuals tease and make fun of each other within certain bounds defined by custom and such antagonism is expressed as "playful antagonism" in a non-threatening environment, it is helpful. Labov (1974) found that "playing the dozens" or "ritualized insults" within AfricanAmerican teen groups is not offensive and can develop interpersonal bonds among the members, as long as done by all involved in a playful manner and within the bounds of the play zone. Conversely, Duncan et al. (1990) argue that such behavior has a negative effect on group behavior and may inhibit the opportunity to develop interpersonal bonds. Furthermore, federal employment laws related to sexual and racial harassment may also create a barrier for that type of humor within the workplace where groups whose members are demographically diverse may be offended by this type of humor. With the appropriate use of inclusionary humor, where the group laughs at itself based on the task or the things they face jointly as a group, a group identity can emerge. When the group is able to move beyond those demographic characteristics and see themselves as an identity group related to the task, the humor has had a functional and beneficial effect. 


\section{HUMOR, STRESS AND THERAPEUTIC BENEFITS}

Humor has been found to be a stress reducer and helpful in improving morale, and it serves as a coping mechanism (Samson \& Gross, 2012). In two studies, Samson and Gross found that positive, but not negative, humor might be an effective form of emotion regulation and serve as an adaptive coping strategy.

From an existential theory perspective, the true value of humor is that it places a person's perception of who he or she is - and the environment - into a "healthy" and "manageable" perspective. Frankl (1978) and Nam, et al. (1994) argue that individuals have to have a sense of purpose and meaning in their lives to have good physical and psychological health. In addition, Mary et al. (2001) summarized Frankl (1978) and Nam et al.'s (1994) findings that the use of humor helps individuals increase their self awareness and learn what they are able to do, lessening their anxiety and increasing their acceptance of themselves and others.

In fact, humor creates observable and measurable physiological, psychological and emotional changes that can facilitate an individual's return to wellness and/or a healthy attitude regarding their ability to retake control of their lives. Humor contributes to one's physiological health by boosting the immune system, raising B-cells, Tcells, and gamma-interferon - a disease-fighting protein. Alternative medicine has incorporated humor as an important facet of its care and wellness initiative. At St. Joseph's Hospital in Houston, Texas, the William Stehlin Foundation has developed a "Living Room," which is an in-house humor center (Humor as Medicine, 1997). Corey (1996) found that counseling clients learn to take themselves and their situations less seriously and to laugh at themselves in healthy ways. Individuals with a sense of humor are better able to assess their current situations, their strengths and weaknesses, and to look at life more realistically and less pessimistically. With the constant changes in the economic environment and uncertainty around jobs, benefits, and pay, this ability is especially crucial to the individual and can also be beneficial to the organization.

\section{HUMOR AND DIVERSITY}

The use of humor in counseling varies, depending on the demographic make-up of the dyad (counselorclient). Different racial ethnic groups respond to humor in qualitatively different ways, and significant problems can arise if those differences are not factored into the counseling relationship. However, when the cultural differences between individuals are considered and humor is used appropriately, the use of humor can break the ice and open the door for trust between individuals. It is important to note that what one demographic group might consider as humor might be considered insulting by another demographic group (Mary et al., 2003). In addition, misunderstanding or minimizing the real differences between groups who look similar can result in greater barriers to communication. For example, the experiences of African-Americans who have lived in the United States their entire lives is vastly different from the experience of African or Caribbean Immigrants. Though the groups may look brown and seem to be part of the same ethnic group, their experiences and their acceptance in the United States, what is expected of them, how they were socialized, and the like, is vastly different. Using cultural humor with Africans about what is uniquely an African-American experience may be very insulting to the Africans and vice versa (Mary et al., 2003). In the case of humor and diversity, the research seems to suggest that it should be used appropriately and with caution.

\section{HUMOR AND COMMUNICATION}

Communication plays a vital role in transmiting information across organization. With the caveat given above, in terms of the use of humor and diversity, the literature suggests that humor promotes effective communication (Lippitt, 1982; Sherman, 1988) and increases the ability to communicate. As Meyer indicates, humor pervasively influences all aspects of communication at home, in politics and at work (Meyer, 1997). Humor's assistance in organizational communication is inarguable. One of the greatest contributions of humor in organizational communication is that it allows expression of facts that were not socialy acceptable, no matter if it is self-enhancing, affiliative or self-defeating. As Ullian (1976) indicates, it is often used to transfer information that is socially risky.

Humor can facilitate expression of feelings that otherwise would not be socially acceptable (Winick, 1976). It allows managers to express themselves without hurting the feelings of others or making the relationships to 
become threatening (Kahn, 1980). Application of positive humor in organization by managers also can make the work meaningful for their employees (Duncan \& Feisal, 1989).

Humor can be a useful tool in assisting the organization in providing information to its employees in ways that can decrease their stress and enhance their cohesiveness. Indeed, humor can assist groups in bonding and forming a group identity, even in times of chaos in their "outer" world. Humor, when used appropriately, can assist in diverse and homogeneous groups and enhance the effectiveness of leadership. However, the appropriate type and timing of humor are important; whether or not it is positive or negative is critical; and the length of time that the employees have been in place also makes a difference. Humor, like any ingredient to the leadership "recipe," must be used in the proper proportion and supported by other organizational mechanisms to be successfully implemented and to result in the types of outcomes important to the individual and the organization.

\section{CONCLUSION}

The strategic and intentional use of humor within the organization can be an important tool which leaders can leverage across the organization. Organizational humor has a number of potential benefits and can be used by management to improve the work environment for its employees. Leaders can increase their effectiveness through the judicious use of humor. Among the organizational benefits are increased group cohesion, reduced stress, increased leadership effectiveness, and improved communication. Caution must be exercised, however, to ensure that humor is used in appropriate settings and with an eye on the particular group with whom it is being used. When there is a demographically heterogeneous group, caution must be exercised. What is a joke for one group could easily be seen as an insult by another group. Indeed, federal employment laws related to discrimination speak to joking which creates a hostile work environment. Whether or not the humor is offensive is from the perspective of the recipient, not the one sharing the humorous joke or anecdote. When these concerns are taken into consideration, both the organization and its members can experience a more relaxing, empowering and productive work environment.

\section{AUTHOR INFORMATION}

Janice Witt Smith has a PhD in Human Resource Management, Labor Relations, Organizational Behavior and Organizational Theory with a minor in Industrial and Organizational Psychology; MBA with Concentration in Human Resource Management; and B.S. in Business Administration and Management. She is also a certified Senior Professional in Human Resource Management (SPHR). Dr. Smith has 20 years of collegiate teaching experience in undergraduate and MBA programs, as well as a background in corporate training and development. Dr. Smith has authored a number of peer-reviewed journal articles and is actively engaged in HR and management consulting, leadership development, employee engagement and executive coaching through her consulting practice. E-mail: jwsmithphd@nc.rr.com

Mak Khojasteh has a DBA, MBA and B.S. in Business Administration with a concentration in Organizational Behavior. He has 28 years of teaching experience at undergraduate as well as MBA and Executive MBA programs. He has published a textbook, Managing Workforce Diversity in Organizations. Dr. Khojasteh is actively involved in leadership development and change management. In addition, Dr. Khojasteh has developed several academic programs, authored a number of peer-reviewed journal articles, mentored junior faculty, and maintained an active consulting practice. E-mail: mak_khojasteh@yahoo.com (Corresponding author)

\section{REFERENCES}

1. Ashforth, B. E. \& Humphrey, R. H. (1995). Labeling processes in the organization: Constructing the individual. Research in Organizational Behavior, 17, 413-61.

2. Avolio, B. J., Howell, J. M., \& Sosik, J. J. (1999). A funny thing happened on the way to the bottom line: Humor as a moderator of leadership style effects. Academy of Management Journal, 42(2), 219-27.

3. $\quad$ Bass, B. M. (1990). Bass and Stogdill's handbook of leadership. New York, NY: Free Press.

4. Berlyn, D. E. (1968). Laughter, humor, and play. In L. Gardner (Ed.), The handbook of social psychology, Vol. III. Reading, MA: Addison-Wesley. 
5. Chapman, A. J., \& Foot, H. C. (1976). Humor and laughter: theory, research and applications. Wiley.

6. Clouse, R. W., \& Spurgeon, K. L. (1995). Corporate analysis of humor. Psychology-A Quarterly Journal of Human Behavior, 32, 1-24.

7. Corey, G. (1996). Theory and practice of counseling and psychotherapy. Pacific Grove, CA: Brooks/Cole.

8. Decker, W. H., \& Rotondo, D. M. (2001). Relationship among gender, type of humor, and perceived leader effectiveness. Journal of Managerial Issues, 13(4), 450-465.

9. Duncan, W. J., \& Feisal, J. P. (1989). No laughing matter: patterns of humor in the workplace. Organizational Dynamics, 17(4), 18-30.

10. Duncan, W. J., Smeltzer, L. R., \& Leap, T. L. (1990). Humor and work: Applications of joking behavior to management. Journal of Management, 16, 255-78.

11. encarta.msn.com/dictionary 1861619198/definition.html

12. Fabrizia, M. M. S., \& Pollio. H. R. (1987). A naturalistic study of humorous activity in the third, seventh, and eleventh grade classroom. 33 Merrill-Palmer Q. 107-128.

13. Frankl, V. (1978). The unheard cry for meaning. New York: Simon and Schuster (Touchstone).

14. Freud, S. (1916). Jokes and their relation to the unconscious. New York: Moffat, Ward.

15. Greatbatch, D., \& Clark, T. (2003). Displaying group cohesiveness: Humour and laughter in the public lectures of management gurus. Human Relations, 56(12), 1515-1544.

16. Gkorezis, P., Hatzithomas, L., \& Petridou, E. (2011). The impact of leader's humor on employees' psychological empowerment: The moderating role of tenure. Journal of Managerial Issues, 23(1), 83-95, 78 .

17. Hatch, M. J., \& Ehrlich, S. B. (1993). Spontaneous humor as an indicator of paradox and ambiguity. Organization Studies, 14(4), 505-526.

18. Heath, R. P. (1997). Humor is serious business. Electric Perspectives, 22(5): 68-80.

19. James, L. M., \& Olson, J. M. (2000). Jeer pressure: The behavioral effects of observing ridicule in others. Personality and Social Psychology Hull, 26(4), 474-85, 2.

20. Jenepher, L.T., \& Ashforth, B.E. (2002). From "I" to "we": The role of putdown humor and identity in the development of a temporary group." Human Relations, 55(1).

21. Kahn, W. A. (1989). Toward a sense of organizational humor: implications for organizations diagnosis and change. Journal of Applied Behavioral Science, 25(1), 45-63.

22. Kuiper, Martin, \& Olinger (1998). Coping Humor, Stress and Cognitive Appraisals. Canadian Journal of Behavioral Science, 25(1), 81-96.

23. Korabak, K., \& Ayman, R. (1989). Should women managers have to act like men? Journal of Management Development, 8(9), 23-32.

24. Labov, W. (1974). The art of sounding and signifying. In W.W. Gage (Ed.), Language in its social setting. Washington, DC: Anthropological Society of Washington, pp. 84-116.

25. Lippitt, G. L. (1982), Humor: A laugh a day keeps the incongruities at bay. Training and Development Journal, 36(11), 98-100.

26. Luthans, F. (Sep. 2002). The need for and meaning of positive organizational behavior. Journal of Organizational Behavior, 23(6), 695.

27. Martin, R. A., Puhlik-Doris, P., Larsen, G., \& Gray, J. (2003). Individual differences in uses of humor and their relation to psychological well-being: Development of the humor styles questionnaire. Journal of Research in Personality, 37(1), 48076.

28. Martineau, W. W. (1972). A Model of the social functions of humor. In J. Goldstein, \& P. McGhee (Eds.), The psychology of humor (pp. 101-125). New York: Academic Press Chapman \& Foot.

29. Mary, F. M., Dupey, P., Torres-Rivera, E., Phan, L. T., \& als. (2001). Ethnic diversity and the use of humor in counseling: Appropriate or Inappropriate? Journal of Counseling and Development: JCD, 79(1), 53-60.

30. Meyer, J. C. (1977). Humor in member narrative: Uniting and dividing the work. Western Journal of Communication, 61, 188-208.

31. Nam, J., Heritage, J., \& Kim, J. (November 1994). Predictors of drug/alcohol abuse and sexual promiscuity of college students. Paper presented at the meeting for the Southern Association for Counselor Education and Supervision, Charlotte, NC.

32. Nevada Health Care Coalition (April 1997). Humor in hospitals. The Human Potential, Inc. [On-line]. Available: http://www.stressed.com 
33. Radcliffe-Brown, A. R. (1940). On joking relationships. Africa: Journal of the international African Institute, pp. 195.

34. Raskin, V. (1985) Semantic mechanisms of humor. Boston, MA: Reidell.

35. Romero, E. J., \& Cruthirds, K. W. (May 2006). The use of humor in the workplace. Academy of Management Perspectives, pp. 58-69.

36. Samson, A., \& Gross, J. (2012). Humor as emotion regulation: The differential consequences of negative versus positive humor. Cognition \& Emotion, 26(2), 375-84.

37. Seligman, M., \& Csikszenetmihali, M. (2000). Positive psychology. American Psychologist, 55, 5-14.

38. Shamir, B. (1995). Social distance and charisma: Theoretical notes and an exploratory study. Leadership Quarterly, 6, 19-48.

39. Sherman, L. W. (1988). Humor and social distance in elementary school children. Humor: International Journal of Humor Research, 1(4), 389-404.

40. Ullian, J. A. (1976). Joking at work. Journal of Communication, 26, 129-33.

41. Winnick, Charles (1976). The social contexts of humor. Journal of Communication, 26(3), $124-28$.

42. Zillman, D. (Spring 1983). Disparagement Humor. In P. K. McGhee \& J. H. Goldstein (Eds.), 1 Handbook of humor research (pp. 145-62). Verlag. 


\section{NOTES}

